\title{
Effect of Motivation and Work Environment on Employee Performance in Work Unit Implementation on the Jakarta Metropolitan I National Road
}

\author{
Guruh Dwi Pratama \\ Univesitas Pamulang \\ Email: guruh.dwipratama@yahoo.com
}

(Received: April 10-2020; revised: may 15-2020; published: June 30-2020)

\begin{abstract}
The purpose of this study was to determine motivation and work environment for employee performance in Work Unit Implementation on the Jakarta Metropolitan I National Road. The method used is descriptive method with an associative approach. The sampling technique used was proportional random sampling with a sample of 60 respondents. The analysis tool uses validity test, reliability test, classic assumption test, regression analysis, correlation coefficient analysis, coefficient of determination analysis and hypothesis testing. The results of this study are that motivation has a positive and significant effect on employee performance by $43.1 \%$. Hypothesis testing is obtained tcount $>$ ttable or $(6.628>2.002)$, so that $\mathrm{H} 0$ is rejected and $\mathrm{H} 1$ is accepted, meaning that there is a positive and significant influence between motivation on employee performance in Work Unit Implementation on the Jakarta Metropolitan I National Road. The work environment has a positive and significant effect on employee performance by $40.7 \%$. Hypothesis testing is obtained tcount> $\mathrm{t}$ table or $(6.311>2.002)$ so that $\mathrm{H} 0$ is rejected and $\mathrm{H} 2$ is accepted, meaning that there is a positive and significant influence between the work environment on employee performance on. Simultaneous test of motivation and work environment has a positive and significant effect on employee performance with a contribution of $48.4 \%$, while the remaining $53 \%$ is influenced by other factors. Hypothesis testing obtained the value of Fcount> F table or (32.194> 2.770), thus $\mathrm{Ho}$ is rejected and $\mathrm{H} 3$ is accepted. This means that there is a positive and significant simultaneous influence between motivation and work environment on employee performance in Work Unit Implementation on the Jakarta Metropolitan I National Road.
\end{abstract}

Keywords: Motivasi, lingkungan kerja, kinerja pegawai.

\section{INTRODUCTION}

Human resource management (HRM) is one of the fields of general management which includes aspects of planning, organizing, implementing and controlling (Hasibuan, 2011; Singodimendjo, 2011; Sulistiyani \& Rosidah, 2013). This process exists in the functions or fields of production, marketing, finance, and staffing. Because human resources (HR) are considered increasingly important in achieving company goals, various experiences and research results in the HR field are systematically collected in what is called human resource management. The term management has meaning as a collection of knowledge about how to manage (manage) human resources.

According to Suhariadi (2013), management is a process of utilizing and utilizing resources, be it financial, machine, material, method, and human resources to achieve the stated organizational goals. To achieve the goals set, the process of integrating, coordinating and 


\author{
26 Jurnal Ilmiah Ilmu Administrasi Publik: Jurnal Pemikiran dan Penelitian Administrasi Publik \\ Volume 9 Number 2, July- December 2019. Page 25-34
}

division of tasks among the resources available in the organization becomes very important to sustain these goals. Along with this, what is meant by the term human resource management (human resource management) is the utilization of development, assessment, rewarding and individual management of organizational members or groups of employees all of which are directed to achieve organizational goals (Bircan \& Gençler, 2015 ; Sinambela, 2016).

Motivation is very important in organizations (Diefendorff \& Seaton, 2015; Kooij \& Kanfer, 2019; Nur, Rahman, \& Musdalifa, 2019; Sutrisno \& Sunarsi, 2019). According to Mangkunegara (2003), motivation is a condition that moves employees to be able to achieve their goals and motives. In theory, various definitions of motivation usually contain wants, hopes, needs, goals, objectives, encouragement and incentives. Employees work with the expectation of getting a salary or wage that can meet these needs. In addition, the fulfillment of the expected needs of employees is to provide service and appreciation by superiors for work performance produced in accordance with the principle of fairness that can motivate employee work (Astuti et al., 2016; Nasrullah et al., 2017; Niswaty et al., 2017; Saggaf et al., 2018; Salam et al., 2018). Without motivation, an employee cannot fulfill his work according to standards because what is motivated in working is not fulfilled (Alfian, Niswaty, Dervish, Arhas, \& Salam, 2019; Astuti, Dervish, Saleh, \& Baharuddin, 2019; Rosmani, Amirullah, \& Saleh, 2015). Even if an employee has the ability to work high but does not have the motivation to complete his task, the final results in his work will not be satisfactory.

The work environment is anything that is around employees that affect themselves in carrying out and completing the tasks given to them in an area (Lestary \& Harmon, 2018; Putra, FR, HN Utami, 2013; Rukhayati, 2018; Senata, Nuridja, \& Suwena, 2014). Performance according to (Suhariadi, 2013) is a function of motivation and ability. To complete a task or job, a person must have a certain degree of willingness and level of ability. A person's willingness and skills are not effective enough to do something without a clear understanding of what will be done and how to do it. Achieving the goals set is one of the benchmarks of individual performance. There are three criteria for evaluating performance, namely (a) individual tasks, (b) individual behavior, (c) individual characteristics.

The problem that arises in the Jakarta I National Road Implementation Center I is the lack of work motivation that can affect performance and affect the social needs of employees so that it becomes very not optimal and effective. Employee motivation is needed to improve employee performance and be a way to direct the power and potential of subordinates to want to work productively. The motivation of the employees of the Center for the Implementation of National Road I declined this can be seen from table 1.

Table 1 can be seen that the level of employee motivation for the 2018 period still needs to be improved because the achievement only reached an average of $66.4 \%$, while those who did not reach the specified criteria reached $33.6 \%$. These results indicate that the level of motivation of the Central Office for the Implementation of the National Road I is still not optimal, overall showing a downward trend. This shows that conditions like this must be immediately reformed so that employees have high motivation. 
Tabel 1.

Percentage Data for the Motivation Category of Employee of the Implementation of the National Road I Jakarta for the 2018 Period

\begin{tabular}{|c|c|c|c|c|c|}
\hline \multirow[t]{2}{*}{ Dimension } & \multirow{2}{*}{$\begin{array}{l}\text { Number of } \\
\text { Employees }\end{array}$} & \multicolumn{2}{|c|}{$\begin{array}{c}\text { Average } \\
\text { Achievement }(\%)\end{array}$} & \multirow{2}{*}{$\begin{array}{c}\text { Target } \\
(\%)\end{array}$} & \multirow[t]{2}{*}{ Information } \\
\hline & & Reached & No & & \\
\hline The need for physiology & 60 & 73 & 27 & 100 & Corrected \\
\hline The need for security & 60 & 71 & 29 & 100 & Corrected \\
\hline Need for Social & 60 & 67 & 33 & 100 & Corrected \\
\hline The Need for Self-Esteem & 60 & 63 & 37 & 100 & Corrected \\
\hline The Need for Self Actualization & 60 & 58 & 42 & 100 & Corrected \\
\hline Average & & 66,4 & 37 & & Corrected \\
\hline
\end{tabular}

In a company that can result in ineffective employee performance not just motivation but there is a work environment must also be considered, at the Jakarta National Road Implementation Center I the work environment is still not effective because the company still lacks facilities within the company.

The Jakarta National Road Implementation Center I assesses employee performance by comparing the target number of work projects with the realization of the work done every year. The following table shows the target of project results and the realization of work at the Jakarta National Road Implementation Center I from 2014 to 2018.

Table 2.

Performance Rating on Center for Implementation of National Roads I

\begin{tabular}{ccccc}
\hline \multirow{2}{*}{ Years } & \multirow{2}{*}{ Target } & Realization & Development \\
\cline { 4 - 5 } & & 50 & 5 & Percentage (\%) \\
\hline 2014 & 55 & 55 & 3 & 90 \\
2015 & 58 & 56 & 6 & 93 \\
2016 & 60 & 62 & 14 & 81 \\
2018 & 76 & 72 & 8 & 90 \\
\hline
\end{tabular}

Based on the data table above, shows that the realization of work in 2014 as many as 50 projects with a percentage of $90 \%$. In 2015 , there were 55 projects with a percentage of $94 \%$. In 2016 , there were 56 projects with a percentage of $93 \%$. In 2017 , there were 62 projects with a percentage of $81 \%$. In 2018, there were 72 projects with a percentage of 90 . This shows that the employee's work productivity is low, because it does not reach the target the company wants. According to Mangkunegara (2005), that performance is the result of quality and quantity achieved by an employee in carrying out their duties in accordance with the responsibilities given to him ".

The performance of employees at the Jakarta National Road Implementation Center I is still considered to be poor. The results of work provided to employees are still not optimal. So that it caused a lot of work to be delayed. The ability of cooperation between fellow employees in doing work is also still not good, there are often mistakes between employees. There are still 
28 Jurnal Ilmiah Ilmu Administrasi Publik: Jurnal Pemikiran dan Penelitian Administrasi Publik
Volume 9 Number 2, July- December 2019. Page 25-34

employees who are less responsible so if something goes wrong or if there is a mistake, loose responsibility or irresponsibility.

\section{METHOD}

The type of data used is quantitative from primary data sources by distributing questionnaires which are then carried out tabulation and feasibility analysis as well as secondary data from various scientific literature. The population in this study were employee of the Jakarta National Road Implementation Center I. Sampling was used saturated sampling technique that is 60 employees. The instrument testing uses validity and reliability tests. From the test of validity and reliability stated valid and reliable, this is evidenced by the value of $r$ count $>r$ table, as well as the instruments used are appropriate and feasible to be forwarded to the next test. Testing for normality using Kolmogorov Smirnof obtained significance greater than 0.50 and thus declared normal. Multicollinearity testing obtained tolerance values $<1$ and IF $<10$ so that it was concluded there was no interference with multicollinearity. Autocorrelation testing obtained the value of Durbin-Watson at an interval of $1.550-2.460$, thus this regression model does not have autocorrelation. Heteroskesdastisitas test with tests (Glejser, 1969) obtained a significance value greater than 0.05 so it was concluded that there was no interference with heteroskesdastisitas.

\section{RESULT AND DISCUSSION}

Regional Center for Implementation of National Roads (BBPJN) Region I, is one of eight National Road Implementation Centers in Indonesia responsible for the procurement and maintenance of national road and bridge infrastructure in the Jakarta, West Java and Banten regions. This institution is under the Directorate General of Highways, Ministry of Public Works. This institution was formed to enhance and encourage national economic growth through accelerating the development of reliable and accountable road and bridge infrastructure to realize the welfare of the community.

\section{Descriptive Analysis}

The criteria of the object under study are based on respondents' responses to the questions about the motivational variable (X1) obtained an average score of 3.90, the work environment variable $(\mathrm{X} 2)$ of 3.86 and the employee performance variable $(\mathrm{Y})$ of 3.92, the third the variables obtained are all scores in the scale range of 3.40 - 4.19 with good criteria.

\section{Multiple Linear Regression Analysis}

This multiple regression test is intended to find out how much influence the variables X1 and $\mathrm{X} 2$ on the $\mathrm{Y}$ variable. In this study motivation (X1) and work environment (X2) on 
employee performance (Y). The following are the results of processed regression data with SPSS version 24 which can be seen in the table 3 :

Table 3

Results of Multiple Regression Processing Motivation Variables (X1) and Work Environment (X2) on Employee Performance (Y)

\begin{tabular}{|c|c|c|c|c|c|c|}
\hline \multicolumn{7}{|c|}{ Coefficients $^{\mathbf{a}}$} \\
\hline \multirow{2}{*}{\multicolumn{2}{|c|}{ Model }} & \multicolumn{2}{|c|}{$\begin{array}{c}\text { Unstandardized } \\
\text { Coefficients }\end{array}$} & \multirow{2}{*}{$\begin{array}{l}\text { Standardized } \\
\text { Coefficients } \\
\text { Beta }\end{array}$} & \multirow[b]{2}{*}{$\mathrm{t}$} & \multirow[b]{2}{*}{ Sig. } \\
\hline & & $\mathrm{B}$ & Std. Error & & & \\
\hline \multirow[t]{3}{*}{1} & (Constant) & 9.939 & 3.663 & & 2.713 & .009 \\
\hline & Motivation (X1) & .395 & .102 & .431 & 3.869 & .000 \\
\hline & Work environment (X2) & .360 & .104 & .387 & 3.475 & .001 \\
\hline
\end{tabular}

a. Dependent Variable: Employee Performance (Y)

Based on the results of the regression calculations in the above table, the regression equation $\mathrm{Y}=9,939+0,395 \mathrm{X} 1+0,360 \mathrm{X} 2$ can be obtained. A constant value of 9,939 means that if the motivation (X1) and work environment (X2) variables are absent then there is an employee performance value (Y) of 9,939 points. A value of 0.395 is interpreted if the constant is constant and there is no change in the work environment variable (X2), then every 1 unit change in the motivation variable (X1) will result in a change in employee performance (Y) of 0.395 points. A value of 0.360 is interpreted if the constant is constant and there is no change in the motivational variable (X1), then every 1 unit change in the work environment variable (X2) will result in a change in employee performance $(\mathrm{Y})$ of 0.360 points.

\section{Analysis of the Coefficient of Determination}

Analysis of the coefficient of determination is intended to determine the percentage of the strength of the relationship between the independent variables on the dependent variable both partially and simultaneously), in this study the motivational variables (X1) and work environment (X2) on employee performance (Y). Following are the results of the calculation of the coefficient of determination processed with SPSS version 24, as follows:

\section{Table 4}

Results of Partial Determination Coefficient Analysis Motivation Variables (X1) on Employee Performance (Y)

\section{Model Summary}

\begin{tabular}{lr|r|r|r}
\hline Model & $\mathrm{R}$ & \multicolumn{1}{c}{ R Square } & Adjusted R Square & Std. Error of the Estimate \\
\hline 1 & $.656^{\mathrm{a}}$ & .431 & .421 & 2.568 \\
\hline
\end{tabular}

a. Predictors: (Constant), Motivation (X1)

Based on the test results in the table above, the R-square value (determination coefficient) of 0.431 is obtained, it can be concluded that the motivation variable (X1) influences the 
30 Jurnal Ilmiah Ilmu Administrasi Publik: Jurnal Pemikiran dan Penelitian Administrasi Publik Volume 9 Number 2, July- December 2019. Page 25-34

employee performance variable $(\mathrm{Y})$ of $43.1 \%$ while the remaining $56.9 \%$ is influenced by other factors.

\section{Table 5}

Results of Analysis of the Coefficient of Determination in the Work Environment (X2) on Employee Performance (Y)

\section{Model Summary}

\begin{tabular}{lr|r|r|r}
\hline Model & $\mathrm{R}$ & \multicolumn{1}{c|}{ R Square } & Adjusted R Square & Std. Error of the Estimate \\
\hline 1 & $.638^{\mathrm{a}}$ & .407 & .397 & 2.621 \\
\hline
\end{tabular}

a. Predictors: (Constant), Work environment (X2)

Based on the test results in the above table, R-square value of 0.407 is obtained, it can be concluded that the work environment variable (X2) influences the employee performance variable (Y) by $40.7 \%$ while the remaining $59.3 \%$ is influenced by other factors.

Table 6

Results of Simultaneous Determination Coefficient Analysis Between Motivation (X1) and Work Environment (X2) on Employee Performance (Y)

\begin{tabular}{ll|rrr}
\hline \multicolumn{4}{c}{ Model Summary } \\
\hline Model & $\mathrm{R}$ & R Square & $\begin{array}{c}\text { Adjusted R } \\
\text { Square }\end{array}$ & Std. Error of the Estimate \\
\hline 1 & $.728^{\mathrm{a}}$ & .530 & .514 & 2.353 \\
\hline
\end{tabular}

a. Predictors: (Constant), Work environment (X2), Motivation (X1)

Based on the test results in the above table, R-square value of 0.530 is obtained, it can be concluded that the motivation variable (X1) and work environment (X2) influence the employee performance variable (Y) by $53 \%$ while the remaining $47 \%$ is influenced by factors Other research that was not done.

\section{Hypothesis test}

To test the hypothesis of motivational variables (X1) and work environment (X2) on employee performance $(\mathrm{Y})$ performed with a statistical test $\mathrm{t}$ (partial test). The results of data processing using SPSS version 24 , with the following results: 
Table 7

Motivation Variable t Test Results (X1)

Coefficients $^{\mathrm{a}}$

\begin{tabular}{|c|c|c|c|c|c|}
\hline \multirow[b]{2}{*}{ Model } & \multicolumn{2}{|c|}{$\begin{array}{c}\text { Unstandardized } \\
\text { Coefficients }\end{array}$} & \multirow{2}{*}{$\begin{array}{c}\text { Standardized } \\
\text { Coefficients } \\
\text { Beta } \\
\end{array}$} & \multirow[b]{2}{*}{$\mathrm{t}$} & \multirow[b]{2}{*}{ Sig. } \\
\hline & B & Std. Error & & & \\
\hline (Constant) & 15.791 & 3.550 & & 4.448 & .000 \\
\hline Motivasi (X1) & .601 & .091 & .656 & 6.628 & .000 \\
\hline
\end{tabular}

a. Dependent Variable: Employee Performance (Y)

Based on the test results in the above table, the value of tcount $>t$ table or $(6.628>2.002)$ is also strengthened by the value of $\rho$ value $<$ Sig. 0.05 or $(0.000<0.05)$. Thus, $\mathrm{H} 0$ is rejected and H1 is accepted, this shows that there is a positive and partially significant effect between motivation on employee performance. The results of data processing using SPSS version 24, with the following results:

\section{Table 8}

\section{T Test Results Work Environment Variable (X2)}

\section{Coefficients $^{\mathrm{a}}$}

\begin{tabular}{|c|c|c|c|c|c|c|}
\hline \multirow{2}{*}{\multicolumn{2}{|c|}{ Model }} & \multicolumn{2}{|c|}{$\begin{array}{c}\text { Unstandardized } \\
\text { Coefficients }\end{array}$} & \multirow{2}{*}{$\begin{array}{c}\text { Standardized } \\
\text { Coefficients } \\
\text { Beta }\end{array}$} & \multirow[b]{2}{*}{$\mathrm{t}$} & \multirow[b]{2}{*}{ Sig. } \\
\hline & & B & Std. Error & & & \\
\hline & (Constant) & 16.354 & 3.638 & & 4.495 & .000 \\
\hline & Work Environment (X2) & .593 & .094 & .638 & 6.311 & .000 \\
\hline
\end{tabular}

a. Dependent Variable: Employee Performance (Y)

Based on the test results in the table above we get the value of $t>t$ table or (6.311> $2.002)$, it is also strengthened by $\rho$ value $<$ Sig. 0.05 or $(0,000<0.05)$. Thus, $\mathrm{H} 0$ is rejected and $\mathrm{H} 2$ is accepted, this shows that there is a positive and partially significant effect between the work environment on employee performance.

To test the effect of motivation and work environment variables simultaneously on employee performance on the Jakarta Metropolitan National Road Implementation Work Unit is carried out with a statistical test $\mathrm{F}$ (simultaneous test) with a significance of 5\%.

\section{Table 9}

\section{Simultaneous Hypothesis (F-Test Results)}

\section{ANOVA $^{\mathrm{a}}$}

\begin{tabular}{llr|r|r|r|c}
\hline & Model & Sum of Squares & \multicolumn{1}{c|}{ df } & Mean Square & \multicolumn{1}{c}{ F } & \multicolumn{1}{c}{ Sig. } \\
\hline 1 & Regression & 356.549 & 2 & 178.274 & 32.194 & $.000^{\mathrm{b}}$ \\
\cline { 2 - 8 } & Residual & 315.635 & 57 & 5.537 & & \\
\hline Total & 672.183 & 59 & & & \\
\hline
\end{tabular}

a. Dependent Variable: Employee Performance (Y)

b. Predictors: (Constant), Work environment (X2), Motivation (X1) 


\footnotetext{
32 Jurnal Ilmiah Ilmu Administrasi Publik: Jurnal Pemikiran dan Penelitian Administrasi Publik Volume 9 Number 2, July- December 2019. Page 25-34
}

Based on the test results in the above table, the value of Fcount $\neg>F$ table or (32.194> $2.770)$ can be strengthened with $\rho$ value $<$ Sig. 0.05 or $(0,000<0.05)$. Thus, $\mathrm{H} 0$ is rejected and $\mathrm{H} 3$ is accepted, this shows that there is a positive and significant effect simultaneously between motivation and work environment on the performance of employees of the Jakarta Metropolitan I National Road.

\section{CONCLUSION}

Motivation has a positive and significant effect on employee performance with a magnitude of influence of $43.1 \%$. Hypothesis testing is obtained tcount> ttable or (6.628> 2.002), thus $\mathrm{HO}$ is rejected and $\mathrm{H} 1$ is accepted meaning there is a positive and significant influence between motivation on employee performance on the Metropolitan National Road Implementation Work Unit. The work environment has a positive and significant effect on employee performance with a magnitude of influence of $40.7 \%$. Hypothesis testing is obtained tcount $>$ ttable or $(6.311>2.002)$, this is reinforced with a probability of $0,000<0.05$, thus $\mathrm{H} 0$ is rejected and $\mathrm{H} 2$ is accepted meaning that there is a positive and significant influence between the work environment on employee work performance on the Road Work Unit Metropolitan National. Motivation and work environment have a positive and significant effect on employee performance with a regression equation $\mathrm{Y}=9,939+0,395 \mathrm{X} 1+0,360 \mathrm{X} 2$. The higher the motivation and work environment, the employee's performance will also increase. The amount of influence is 53\% while the remaining $47 \%$ is influenced by other factors. Hypothesis testing obtained by the value of Fcount> Ftable or (32.194> 2.770), it is also strengthened with a probability of $0,000<0.05$. Thus $\mathrm{H} 0$ is rejected and $\mathrm{H} 3$ is accepted. This means that there is a positive and significant simultaneous influence between motivation and work environment on employee performance at the Jakarta Metropolitan I National Road Implementation Work Unit. in this study means that if the company wants to improve employee performance, it can be done by increasing motivation and / or improving the work environment. Increased motivation will produce more performance improvement than changes in the work environment.

\section{REFERENCES}

Alfian, M., Niswaty, R., Darwis, M., Arhas, S. H., \& Salam, R. (2019). Motivasi Kerja Pegawai pada Sekretariat Dewan Perwakilan Rakyat Daerah Kabupaten Gowa. 1, 35-44.

Astuti, A., Darwis, M., Saleh, S., \& Baharuddin, A. (2019). Study of Employee work motivation at PT Bank Sulselbar Makassar Main Branch. Jurnal Office, 4(2), 37-52.

Bircan, İ., \& Gençler, F. (2015). Analysis of Innovation-Based Human Resources for Sustainable Development. Procedia - Social and Behavioral Sciences, 195, 1348-1354. https://doi.org/https://doi.org/10.1016/j.sbspro.2015.06.321

Diefendorff, J. M., \& Seaton, G. A. (2015). Work Motivation (J. D. B. T.-I. E. of the S. \& B. S. (Second E. Wright, ed.). https://doi.org/https://doi.org/10.1016/B978-0-08-097086- 


\subsection{6-9}

DR. A.A Anwar Prabu Mangkunegara, M. (2005). Evaluasi Kinerja SDM. In Refika Aditama.

Glejser, H. (1969). A New Test for Heteroskedasticity. Journal of the American Statistical Association. https://doi.org/10.1080/01621459.1969.10500976

Hasibuan, M. S. P. (2011). Manajemen Sumber Daya Manusia. Edisi Revisi Jakarta: Bumi Aksara.

Kooij, D. T. A. M., \& Kanfer, R. (2019). Chapter 20 - Lifespan Perspectives on Work Motivation (B. B. Baltes, C. W. Rudolph, \& H. B. T.-W. A. the L. Zacher, eds.). https://doi.org/https://doi.org/10.1016/B978-0-12-812756-8.00020-7

Lestary, L., \& Harmon, H. (2018). Pengaruh Lingkungan Kerja Terhadap Kinerja Karyawan. Jurnal Riset Bisnis Dan Investasi. https://doi.org/10.35697/jrbi.v3i2.937

Mangkunegara, A. A. A. P. (2003). Manajemen Sumber Daya Manusia Perusahaan. In Remaja Rosdakarya. https://doi.org/10.1038/cddis.2011.1

Nasrullah, M., Salam, R., Pratiwi, D., \& Niswaty, R. (2017). Motivasi Kerja Pegawai Di Kantor Keyahbandaran Utama Makassar. Jurnal Ilmiah Manajemen Dan Bisnis, 18(2), 206-211.

Niswaty, R., Rusbiati, S., Jamaluddin, J., \& Salam, R. (2017). The Influence of Teacher's Reinforcement for Students Motivation. International Conference on Education, Science, Art and Technology, 148-152.

Nur, F., Rahman, U., \& Musdalifa, M. (2019). Effect of Motivation and Job Satisfaction on Teacher Performance in Private Madrasah Aliyah in Maros Regency. Jurnal Ilmiah Ilmu Administrasi Publik, 9(1), 9-18.

Putra, F.R., H. N. Utami, M. S. H. (2013). Pengaruh Lingkungan Kerja Terhadap Kinerja. Jurnal Administrasi Bisnis.

Rosmani, S. R., Amirullah, A. H., \& Saleh, S. (2015). Pengaruh Motivasi Kerja terhadap Kinerja Pegawai pada Dinas Kebersihan dan Pertamanan Kabupaten Soppeng. Jurnal Office, 1(1), 31-37.

Rukhayati. (2018). Pengaruh Motivasi Dan Disiplin Kerja Terhadap Kinerja Karyawan Di Puskesmas Talise. Jurnal Sinar Manajemen.

Saggaf, M. S., Nasriyah, N., Salam, R., \& Wirawan, H. (2018). The Influence of Teacher's Pedagogic Competence on Learning Motivation of Student of Office Administration Expertise Package.

Salam, R., Akib, H., \& Daraba, D. (2018). Utilization of Learning Media In Motivating Student Learning.

Senata, I. W., Nuridja, I. M., \& Suwena, K. R. (2014). Pengaruh Lingkungan Kerja Terhadap Produktivitas Kerja Karyawan UD. Kembang Sari Kabupaten Bandung Tahun 2012. Jurnal Pendidikan Ekonomi Undiksha.

Sinambela, L. P. (2016). Manajemen Sumber Daya Manusia, Membangun Tim Kerja yang Solid untuk Meningkatkan Kinerja. 
34 Jurnal Ilmiah Ilmu Administrasi Publik: Jurnal Pemikiran dan Penelitian Administrasi Publik Volume 9 Number 2, July- December 2019. Page 25-34

Singodimendjo. (2011). Manajemen Sumber Daya Manusia. Jakarta: Bumi Aksara.

Suhariadi, F. (2013). Manajemen Sumber Daya Manusia: Dalam Pendekatan Teoritis-Praktis. Surabaya: Airlangga University Press.

Sulistiyani, A. T., \& Rosidah. (2013). Manajemen Sumber Daya Manusia. Yogyakarta: Gadjah Mada University Press.

Sutrisno, S., \& Sunarsi, D. (2019). The Effect of Work Motivation and Discipline on Employee Productivity at PT. Anugerah Agung in Jakarta. Jurnal Ad'ministrare, 6(2), 187-196. 